\title{
The “Mother Complex” of Martha Quest
}

\author{
Rukhsana Rahim Chowdhury \\ BRAC University, Dhaka, Bangladesh
}

\begin{abstract}
Human experience can best be understood in the framework of collective social relations. Like any other tie, the mother-daughter relationship is forged not in isolation but informed by cultural, historical, and social values, circumstances, and practices. The twentieth century has witnessed the greatest changes in world history. As an outcome of the noticeable shift in gender ideologies in the last half of that century, modern mothers and daughters struggled to experience a union, a bond, an understanding of themselves and the world around them. Clash of tradition and modernity in ideals and mores can be held accountable for the consequential neurotic development of the psyche in twentieth century mothers and daughters. Doris Lessing's writings reflect the way in which these complex changes in society affect family relationships. Her first novel of the Children of Violence series, Martha Quest, is an apt study of a mother and her daughter's struggle with their newly defined roles in society. This paper will seek to examine the conflicts that are encountered in the wake of such adjustments by contemporary mothers and daughters. In order to do so, the study will focus on an exploration of the kind of issues that Martha Quest and May Quest experience in Lessing's Martha Quest through approaches available in works by Carl Jung on his theory of the "mother complex".
\end{abstract}

Keywords: gender roles, “mother complex”, resistance, psychic dilemmas, Matrophobia, motherhood

\section{Introduction}

The mother stands for the victim in ourselves, the unfree woman, the martyr. -Adrienne Rich,

Of Woman Born: Motherhood as Experience and Institution (1986)

Any mother-daughter relationship is forged not in isolation but is informed by cultural, historical, and social values, circumstances, and practices. The twentieth century has witnessed the greatest changes in world history. Among other shifts and changes, gender ideologies also underwent a degree of revision which found modern mothers and daughters struggling to experience a union with, and a bond or an understanding of, themselves and the world around them. Clash of tradition and modernity in ideals and mores can be held accountable for the consequential neurotic development of the psyche in twentieth century mothers and daughters. Doris Lessing's writings reflect the way in which these complex changes in society affect family relationships. Her first novel of the Children of Violence series, Martha Quest, is an apt study of a mother and her daughter's struggle with their newly defined roles in society. This paper will seek to examine the conflicts that are encountered by modern mothers and daughters. In order to do so, the study will focus on an exploration of the kind of issues that Martha Quest and May Quest experience and deal with, in Lessing's Martha Quest through approaches available in works by Carl Jung on his theory of the "mother complex".

Rukhsana Rahim Chowdhury, M.A., Senior Lecturer, Department of English and Humanities, BRAC University. 
The twentieth century has seen two world wars, great delusions and even greater disappointments consequentially giving birth to new ideologies. In the backdrop of a gradual loss of faith in tradition and religion, Socialism offered a new hope to many. Doris Lessing believed in the socialist philosophy that human experience can be understood in the context of social relations which in turn open up the possibility of personal transformation. She believed that the psychic dilemmas of modern womanhood are rooted in the social relations of the modern family. This is perceptible in the delineations of most of the mother-daughter relationships in her writing. Equations in the relationships of Mary Turner and her feminist mother in The Grass is Singing, Janna Somers and her surrogate mother Maudie in The Diaries of Jane Somers and Alice Melling and her mother Dorothy in The Good Terrorist, clearly reflect Lessing's concern and preoccupation with her vision of the contemporary mother-daughter relationship.

For Martha Quest - living in Africa in the early 20th century — there is no role model, no living woman to guide her. She lives with a father constantly fussing over his "illness" and a mother determinedly trying to hold on to the trends and values of "home" - that for her was and always would be, a Victorian England—which are completely out of sync in this world. She is a soul struggling against the traditions and mores of the past and is in a state of transition into a modern girl of a modern era. Her dilemma is that being raised by a "traditional" mother, she finds it immensely difficult to hold on to a sound sense of her own identity, her individuality which would be free of a maternal persuasion. According to Rosen (1978), Martha longs to escape from the inevitable destiny of "marriage and motherhood" (p. 54). Eventually, she does succeed in escaping from home not into a marriage like her mother's tradition would have desired, but to create a life for herself, far removed from her mother's heavy and oppressively confining maternal influence.

\section{Resistance to the "Mother Complex"}

But when she fights against the mother she may, at the risk of injury to her instincts, attain to greater consciousness, because in repudiating the mother she repudiates all that is obscure, instinctive, ambiguous, and unconscious in her own nature. (Jung, 1969, p. 99)

Historically, the concept of motherhood and maternity has been worshipped through the ages. Child psychologists unanimously agree that mothers greatly influence their children's emotional and social condition through their own expressive and affective behavior. For Lessing's protagonist, her mother's dogmatic attitude regarding a woman's sexual growth, role in society, merit, ambitions etc., served as the springboard for conflict between the two women.

Martha Quest is a young teenager who lives on a farm owned by her father in the fictional African town of Zambesia in the 1940s. Initially it was her mother's colonial outlook which prevented her from mixing freely with her neighbours or living a free life as she desired. May Quest's failure to understand the needs, wishes, and desires of Martha, creates a sense of emotional alienation and exile in her daughter and thus this mother-daughter relationship seems to embody only angst and anger.

Martha has a fiercely independent nature and temperament and has a clearly defined set of her own values. She does not shy away from voicing her opinions, and expressing her point of view in front of her parents and neighbours. Her personality reflects a pendulum oscillating between sheer indolence and sharp insight. Sadly the mother does not sympathise with or understand this attitude. Thus Martha grows into an intellectual introvert who seeks self-fulfillment and intellectual freedom in books supplied by her Jewish friends Solly and Joss Cohen. Her readings raise in her the awareness that neurotic, fragmented mother-daughter relation is a 
20th century dilemma confronting the modern women. Lessing shows that this heightened self-consciousness was developed especially as a result of Martha's antagonistic feelings for and relationship with her mother. Martha's need for what Rosen (1978) calls a "symbiotic attachment” (p. 56) clashes with her strong desire to attain her own individuality as Mrs. Quest's influence and presence in her life is oppressive and domineering.

The narrative offers no clarification for Martha's resentment towards her mother as Lessing invites her readers to draw their own conclusions. The mother-daughter duo fights over various issues. Concerns like having friendship with the Cohens, going for dance parties, even walking alone in the veld become matters of huge disputes. Martha's desire to dress according to her own taste and inclination and read books on politics, psychology, and sex are all a result of her reluctance to conform to her mother's ideal of a daughter. She tells herself every time, that “1 won’t give in. I won't” (Lessing, 1995, p. 26). Her mother on the other hand, feels that "she did not know what to do with Martha, who seemed bent on behaving so as to make her mother as unhappy as possible” (Lessing, 1995, p. 16). Martha knows well that her mother's sorrow about her is too personal, because her failure to conform will reflect upon Mrs. Quest's maternal inability to control and guide her daughter. And for a lady of Mrs. Quest's social stature it was quite shameful, to let a daughter rebel and resist the mother's control. A mother is traditionally regarded by society as being the primary source of encouragement, understanding, and nurture for her children. The fundamental conflict arises when Martha's mother, a product of the patriarchal mindset, attempts to impose patriarchal principles and values on the daughter. She feels that it would be a matter of great disappointment for a mother to find that the child whom she has so lovingly raised with hopes of seeing her own self reflected, has other "modern" ideas.

These threads of conflict and tension in the mother-daughter relationship find place in Carl Gustav Jung's discourse on human psyche. He discussed an individual's “archetypes”, i.e., universal thought-forms or mental images that influence an individual's feelings and actions. Discussing archetypes such as the anima, the mother, the child, the shadow, etc., Jung considered the mother as the most important archetype because it seemed to contain all else. According to Jung, when there is an imbalance of the archetype in a person, he suffers from the mother "complex". The mother complex is a potentially active component of one's psyche, informed first of all by experience of the personal mother, then by significant contact with other women and by collective assumptions. The constellation of a mother complex has differing effects according to whether it appears in a son or in a daughter. This mother complex can make a woman go to any lengths to not be like her biological mother. She may carve out a sphere of her own, for example, becoming an intellectual to show up her mother's lack of education. A choice of marriage partner may be to antagonize and move away from the mother.

In his essay, Psychological Aspects of the Mother Archetypes, Jung (1969) shows two opposing aspects of the archetypal "mother". These twin aspects are generally referred to in Jungian psychology as the "good or loving mother" and the "terrible mother". The qualities associated with the great mother are "maternal solicitude and sympathy; the magic authority of the female; the wisdom and spiritual exaltation that transcend reason; any helpful instinct or impulse; all that is benign, all that cherishes and sustains, that fosters growth and fertility” (Jung, 1969, p. 82). Good mothers are those who evoke devotion and awe in their off springs. An ambivalent aspect of the mother is in the mother symbols having an evil connotation, for example, deep waters, the grave, and nightmares. Jung cites the example of Virgin Mary, mother of Jesus Christ as a personification of this ambivalence. She is "not only the Lord's mother, but also, according to the medieval allegories, his cross". In Indian mythology, this loving and terrible mother factor is characterized by the goddess Kali.

Fighting her own demons, Martha seeks the Jungian "good" and "loving mother" but is confronted instead 
with the "terrible mother" who reserves her maternal love for her son and subjects Martha to attempts to turn her into a conventional or rather, an Edwardian lady. She feels that her mother never loved her and fiercely resents her mother's conventional mind-set. Her mother represents values and ideas, which she is unable to identify with. This impossibility of identification with the mother creates a huge void in her life as she confronts the absence of a model to follow. The daughter, therefore, seeks some kind of solace in the bosom of the Jungian "earth mother", which for her is, the African veld. After a nasty spat with her mother on the issue of boys and marriage, Martha "marched off down the garden, and ran into the bush" (Lessing, 1995, p. 9). Here she lies down in the long grass under a tree and keeps repeating to herself that "her mother was hateful" (Lessing, 1995, p. 10). We see that for a long time,

...she remained under the tree, whose roots were hard under her back, like a second spine, and looked up through the leaves to the sky, which shone in a bronze clamour of light. She ripped the fleshy leaves between her fingers, and thought again of her mother. (Lessing, 1995, p. 14)

It is apparent then that unfortunately this also turns out to be a futile attempt. Her beloved farm and the adjoining open land fail to arouse any feeling of devotion or awe, or provide the promise of the protection which she subconsciously sought. She was "so resentful of her... parents that the resentment overflowed into everything near her” (Lessing, 1995, p. 5). She liked taking long and solitary walks in the veld. During one such walk an experience described by Lessing was when "the bush lay quiet about her, a bare slope of... grass moving... and she stood quite still, waiting for the moment...” (Lessing, 1995, p. 66). "Suddenly the feeling in Martha deepened and... she knew... what she had been waiting for... was a pain, not a happiness... " (Lessing, 1995, p. 67). She accepted the experience as "incidental to the experience of adolescence” (Lessing, 1995, p. 67) and was left feeling irritable, "flat and stale". In the absence of a mother-daughter bond, she cannot recapture the memory of an experience which she never had in the first place. In her estimation, Mrs.Quest epitomizes the Jungian definition of the "terrible mother" and so Martha is left feeling confused, empty, angry and caged more than ever. Her fervent desire for freedom and independence from the mother is encapsulated in her intellectual superiority. She struggles to free herself and in extension, her creative energies, the "libido" from an emotional entanglement with the mother. One night she dreams of a land bordered by sea. Interpreting Jung's ideas regarding the mother archetype, it can be said that deep waters symbolise an evil aspect of the mother where the deep dark water becomes the cold embrace of the mother's bosom which instead of providing solace seeks to smother the child. The dream of the vast sea represents Martha's unfulfilled wish for fusion with the "good mother".

As mentioned earlier the mother complex results in a desire to attain a superior intellect in order to highlight the mother's (supposed) lack of education and thereby create a space where the mother has no place. This clear form of resistance against the mother is evident in Martha's habit of reading. She successfully excludes and evades her mother in a world of books. Mrs. Quest often imprisoned Martha emotionally through her tears. Just before her matric exams, Martha contracts the "pink eye" and was brought home by her mother to give rest to her eyes. Martha goes on reading books, prompting her mother to remark, "You do it on purpose to upset me!” (Lessing, 1995, p. 30). The only way for Martha to get out of this emotional imprisonment was to wish for a different social order, where everything her mother rejected and condemned will be the norm of life. Hence at night she dreams of a city with a new and different society where equality and integrity are the norm.

1 “Metamorphoses of the Libido” from The Second Sex (1956), Beauvoir, p. 167. 
This dream reflects her growing frustration with the condition of her life. She is often reprimanded for breaking the boundaries set by society for white women. The very English Mrs. Quest with all her colonial ideas was dead set against allowing Martha to walk back home from the market. She was of the opinion that "A young White girl walking alone” (Lessing, 1995, p. 50) invited getting raped by the Black natives. Martha vehemently disagreed and held on to her claim that rape is not colour or creed based and that a White man is just as likely to rape a Black girl. The mother ends the argument with the ominous comment that "girls get raped" (Lessing, 1995, p. 51). Her relationship with the Cohen brothers was not free and easy as this too was frowned upon by Mrs. Quest who had strong anti-Semitic feelings. Martha agrees with Joss that she "dislikes racial prejudice... including anti-Semitism” (Lessing, 1995, p. 56). In the city of her dreams, everyone, the Cohens, the black, the white, and the brown will be welcome, except people like her parents who had "pettiness of vision and small understanding” (Lessing, 1995, p. 17).

Martha suffers a rude shock while in the car with Mr. McFarline. Later, her indignation at his seductive behaviour was met by her mother with the response that, "Nonsense, you're imagining it, he couldn't have done" (Lessing, 1995, p. 63). This expresses the difference in attitude between the two generations. The older generation believed that sex was something that should not be discussed openly and honestly. The mother refuses to admit her daughter's physical maturity and related problems. Her reaction suggests that at 17, Martha was too young for such attentions. She is desperately trying to shield the daughter from the seedy side of society and the daughter with ideas of equality and justice is fighting to expose the pretensions of this very society.

For Martha, emancipation is in independence from the controlling grip of her mother who was seen as an enemy. Their relationship was so strained that fighting and arguing became a daily routine. She would approach everything her mother said with a lot of misgiving: “...at the slightest remark from her mother she was impelled to take it up, examine it, and hand it back, like a challenge...” (Lessing, 1995, p. 8). When invited to a dance at the Van Rensbergs, Mrs. Quest insists on dressing her in a childish frock believing this would make her appear sexually unattractive to the boys. Martha resists this by stitching a new dress herself and defiantly wearing the provocative dress to the party.

Martha's growing alienation from her mother propels her towards a quest for her own identity. For Martha the farm meant being near her mother and mother meant domination. She feared at every turn, her mother's influence upon her personality and she resisted it always.

...she was having terrible nightmares of being tied hand and foot under the wheels of a locomotive, or struggling waist-deep in quicksands, or eternally climbing a staircase that moved backwards under her. She felt that some kind of spell had been put on her. (Lessing, 1995, p. 37)

Escape from this spell and independence from her mother's domination is seen in the resolution to leave the farm for the city. Martha's decision echoes Beauvoir's thought that a woman can achieve independence only in work. A woman who can financially support herself can also achieve a form of liberation. So she leaves the farm for the city but unfortunately, even here the mother continues to interfere, leaving Martha with the feeling that "something unpleasant would happen, because it always did" (Lessing, 1995, p. 158). In Mrs. Gunn's house after her mother's visit: She flung all the clothes out on to the floor, and then rearranged them to her own taste, though no outsider could have seen any difference; she pushed the bed back to what she imagined had been its old position (Lessing, 1995, p.104). 


\section{Martha's Matrophobia}

Matrophobia... is the fear not of one's mother or of motherhood but of becoming one's mother. -Adrienne Rich,

italicized in original, 1986, p. 235

Lynn Luria Sukenick, an American poet coined the term "matrophobia” in her work, "Feeling and Reason in Doris Lessings' Fiction”. Lessing believes that modernity has destroyed the role of motherhood and marriage as a fulfilling "choice". Adrienne Rich echoes this thought in her book, Of Woman Born, where she explores the contemporary mother-daughter relationship. Rich states that "Matrophobia can be seen as a womanly splitting of the self, in the desire to become purged once and for all of our mother's bondage, to become individuated and free” (Rich, 1986, p. 236). Martha’s matrophobia leads to her struggle to break free of her mother's influence and subsequently flee "home" and land in the very mess she wanted to avoid, namely, "marriage".

Martha finds herself in confrontation with the modern world's dilemma in her relationship with her mother and exhibits the symptoms of matrophobia, which is the fear of becoming one's mother and leads to a search for individual desire and freedom. This is apparent in her fervent desire not to be "bitter and nagging and dissatisfied like her mother” (Lessing, 1995, p. 20). This desire completely echoes Jung's thoughts when he says that such a person is the "supreme example of the negative mother-complex. The motto of this type is: Anything, so long as it is not like Mother!” (Jung, 1969, p. 90).

Her self-respect is fashioned out of her sense of difference from the woman who hovers uselessly in the margins of her life. Although it is Martha's nature to behave sensibly, her common sense is reinforced by her desire to avoid the manipulative histrionics, the mindless tabulations of inconsequential matters, the cruel helplessness, which seem to inform repeatedly the older woman's behavior. (Sukenick, 1973, p. 518)

She finds herself to be in constant confrontation with the mother figure so much so that "at the slightest remark from her mother she was impelled to take it up, examine it, and hand it back, like a challenge” (Lessing, 1995, p. 8). This cathexis between mother and daughter makes her feel oppressed by the idea of having to lead the same "dull staple" of their lives (Lessing, 1995, p. 6) and later decides that "she must not sink into being a mere housewife” (Lessing, 1966, p. 112). Mrs. Quest’s vain attempts to instill ideas of conventional femininity only serve to make Martha even more rebellious and resistant. Martha basically resents her mother as reflecting the conventional mind-set she embodied the patriarchal myth that good mothers know everything necessary for raising perfect children. This knowledge burdened her relationship with her daughter who thinks of using her body as a weapon against her mother's prudish, Victorian attitude. May Quest is a product of the modern, post world war world and is plagued by her own neuroses. Her own strictly Victorian upbringing is the biggest hurdle in the way of a sound mother-daughter bond. On the one hand, she finds herself lauding the values of the Victorian-Edwardian era and on the other hand she cannot help but appreciate and simultaneously be concerned about the freedoms inherent in the modern age. She fails to reconcile modern thinking with established traditions. After her marriage she expected to lord over a perfect and well kept household following the English traditions. The family's move to Africa carried dreams of a better life. But then reality struck. The Whites who went to Africa with big dreams of making money and eventually returning to their home land, became frustrated with the realisation that they do not make enough to return. They live on and on in the temporary thatched houses without ever altering it, year after year, counting on a good crop that would liberate them finally from the claustrophobic, yet physically, vast veld. Thus Mrs. Quest appears as a victim of the imperial 
system that landed her in Africa. She is not a thoroughly monstrous and authoritarian figure, but is rather caught in the same chain of being that jeopardizes her daughter's individualism. Subsequently Mrs. Quest appears as a "tired and disappointed but decided matron" who has transfered all her dashed hopes and ambitions to her daughter. Setting up a successful daughter in the world becomes her reason for existence. She wants Martha to have a good education and a career and hopes eventually to see her well settled in marriage.

The mother completely fails to understand her daughter even on her wedding day. She arrives to find guests already there and does not comprehend that this was no conventional, traditional wedding ceremony but a rather modern exchange of vows where gestures like the father "giving away" his daughter's hand in marriage to another man become redundant. She could only experience a feeling of immense relief that she had finally been able to succeed in carrying out her motherly duty of getting her daughter "properly married" (Lessing, 1995, p. 319). Ironically the daughter knew even when she was entering into this marriage that "she would not stay married to him” (Lessing, 1995, p. 315). Lessing here reflects the cultural code of the society where a girl marries at a very young age. This is due to Martha's impression of marriage as an escape route from the mother.

\section{Conclusion}

Doris Lessing always distanced herself from the idea of feminism and despised being referred to as a feminist. In Martha Quest, she has created a heroine who is not a victim of the patriarchal order, but is a woman haunted by matrophobia. Her neuroses are reflected in her mother complex. Lessing's protagonist is driven to assert her own individuality and will, independent of any emotional shackle. Martha's fervent desire for freedom and independence from the mother is encapsulated in her intellectual superiority. She struggles to free herself and in extension, her creative energies from an emotional entanglement with the mother. She eventually succeeds in resisting the mother complex and freeing herself from the effects of matrophobia even if only temporarily. Towards the end of the novel we find a heroine who has thrown off the fetters and is independent enough to take such major decisions as marriage although her mother complex ensures that this would only be a temporary form of escape or refuge.

\section{References}

Berets, R. (1980). A Jungian interpretation of the dream sequence in Doris Lessing's “The Summer Before the Dark”. Special Issue of Modern Fiction Studies, 261(1), 117-31

Friday, N. (1977). My mother/My self: The daughter's search for identity. New York: Delacorte Press.

Holmquist, I. (1980). From society to nature: A study of Doris Lessing's children of violence. Göteborg: Acta Universitatis Gothoburgensis.

Jean, K. (1991). Jung’s “Dual Mother” in Joyce’s Ulysses: An illustrated psychoanalytic intertext. Journal of Modern Literature, XVII(4), 477-489.

Jung, C. G. (1969). Psychological aspects of the mother archetypes. New York: Princeton University Press.

Lessing, D. (1966). A proper marriage. London: Granada Publishing Ltd..

Lessing, D. (1995). Martha Quest. New York: HarperCollins Publishers.

Reventos, M. D. M. (1996). The obscure maternal double: The mother/daughter relationship represented in and out of Matrophobia. Atlantis, 18(1/2), 286-294.

Rich, A. (1986). Of woman born: Motherhood as experience and institution. New York: W. W. Norton \& Co.

Rosen, E. I. (1978). Martha’s “Quest” in Lessing’s “Children of violence”. Frontiers: A Journal of Women Studies, 3(2), 54-59.

Simone de Beauvoir, The Second Sex.1956. Trans. \& ed. H. M. Parshley, London: Lowe \& Brydone (Printers) Ltd.

Sukenick, L. (1973). Feeling and reason in Doris Lessing's fiction. Retrieved from http://www.jstor.org/stable/1207470 